\title{
Discussion of the Programs of Work in the Primary Grades of the Chicago Institute
}

\author{
Flora J. Cooke
}

\section{Correlation of Work}

It was made evident in the discussion of an ideal course of study at the lllinois State Teachers' Association at Springfield, that the programs and grade outlines which appear each month in the Course of STUDy do not clearly represent the work done by the children of the Chicago Institute.

A fixed program is at best a most artificial thing. That in the Chicago Institute grows out of a consideration of the right of the whole school community to the use of the physical and manual training rooms, and that of each child to his share of the teacher's attention. For the sake of a clearer discussion, we take the liberty of presenting the program for the First Grade for the present quarter. The programs of the other three primary grades are similar, with the exception that the teacher of French assists Miss Van Hoesen in the Third and Fourth Grades in giving one literature, one sloyd, one sewing, and one nature study lesson each week. Thus the children learn French incidentally by the same general method that they learned to speak, read, and write English; i. e., through imitation, and prompted by a desire for expression, and by a normal childish curiosity, they soon begin to speak and read French.

It will be understood that the program given below is only a general guide. It can be changed and shifted to suit the special necessities of the children whenever such changes do not interfere with the movement of other classes in the school.
For instance, history is down on this program for Monday, Tuesday, and Wednesday, and geography for Thursday and Friday. As the geography is only another phase of this same work, it may be better to emphasize the geographical aspect on Tuesday rather than on Friday, and this will often be done. Again, they may need to observe in history on Monday, read in history on Tuesday, and write on Wednesday; or it may be better to have all three forms of work in one lesson each day. Therefore it is manifestly impossible to put down upon the program exactly what the children will be doing at a given time. Yet all modes of study are as a rule considered as absolutely essential to the study of any subject worth thirty minutes of the children's time.

It was asserted at the State meeting that twenty-two separate activities were demanded of the primary children of the Chicago Institute each week, and that reading, writing, and number received almost no attention according to the grade programs. Such an interpretation of the programs may be natural from a first glance at them, but it is utterly wrong. There is absolutely no isolated activity demanded for the sake of the practical training gained through that activity. The children do not take, as implied, an eight-year graded course in sewing, cooking, sloyd, painting, and modeling for the sake of learning to do these manual things. Such training, per se, surely does not belong to a public school education. These activities are in every case used by the children as means to some 
FIRST GRADE PROGRAM, WINTER QUARTER

\begin{tabular}{|c|c|c|c|c|c|c|c|}
\hline TEACHERS. & ROOM. & HOUR. & MONDAY. & TUESDAY. & WEDNESDAY. & THURSDAY.- & FRIDAY. \\
\hline $\begin{array}{l}\text { Cooke } \\
\text { Atwood } \\
\text { Allen } \\
\text { Atwood }\end{array}$ & $\mid \begin{array}{cc}\text { A. } \& \text { C. } \\
\text { A. of } & \text { S. } \\
8 \\
5\end{array}$ & $\begin{array}{c}9: 00 \\
\text { to } \\
9: 30 \\
\end{array}$ & Cooking. & Nat. Study. & Rhythm. & Rhythm. & Nat. Study. \\
\hline $\begin{array}{l}\text { Cooke } \\
\text { Atwood } \\
\text { Atwood } \\
\text { Hollister }\end{array}$ & $\mid \begin{array}{cc}\text { A. \& } & \text { C. } \\
\text { A. of } & \text { S. } \\
5 \\
\text { Sloyd. }\end{array}$ & $\begin{array}{c}9: 30 \\
\text { to } \\
10: 00\end{array}$ & Cooking. & Art. & O. Read. & Nat. Study. & Clay. \\
\hline
\end{tabular}

TEN-MINUTE RUN.

\begin{tabular}{|c|c|c|c|c|c|c|c|}
\hline $\begin{array}{l}\text { Cooke } \\
\text { Atwood }\end{array}$ & $\begin{array}{l}5 \\
5\end{array}$ & $\begin{array}{l}\text { I0:10 } \\
\text { to } \\
10: 40\end{array}$ & Literature. & Number. & Seat Work. & Literature. & Number. \\
\hline & & $\begin{array}{l}10: 45 \\
11: 05 \\
\end{array}$ & \multicolumn{5}{|c|}{ MORNING EXERCISES. } \\
\hline & & $\begin{array}{l}\text { II }: 05 \\
\text { to } \\
\text { II }\end{array}$ & \multicolumn{5}{|c|}{ LUNCH. } \\
\hline $\begin{array}{l}\text { Atwood } \\
\text { Cooke } \\
\text { Goodrich }\end{array}$ & $\underset{5}{5}$ & $\begin{array}{c}11: 30 \\
\text { to } \\
12: 00\end{array}$ & Number. & Library. & Music. & Geography. & Geography. \\
\hline $\begin{array}{l}\text { Atwood } \\
\text { Crawford } \\
\text { Champlin }\end{array}$ & $\begin{array}{l}5 \\
\text { Gym. } \\
\text { Sloyd. }\end{array}$ & $\begin{array}{l}12: 00 \\
\text { to } \\
12: 30\end{array}$ & Gen. Ex. & Gymnastics. & Sloyd. & Gymnastics. & Sloyd. \\
\hline $\begin{array}{l}\text { Atwood } \\
\text { Goodrich }\end{array}$ & $\begin{array}{l}5 \\
5\end{array}$ & $\begin{array}{c}12: 30 \\
\text { to } \\
1: 00\end{array}$ & History. & History. & History. & O. Read. & Music. \\
\hline
\end{tabular}

A. \& C. Arts and Crafts.

A. of S. Academy of Science.

desired end, and the child merely uses all his mental and physical powers to accomplish that end. He is thus trained naturally and incidentally as the race was trained, and he acquires skill through the rational use of his mind and body in work and play. Thus the doing of many things during a day does not necessarily mean mental dissipation; it may be exactly the opposite thing - strong image growth, concentration, thoroughness in one piece of work.

For instance, suppose during the day that a child plans to make a dictionary.

In manual training he measures and cuts it out.

In number he finds out how many leaves he needs to hold the alphabet, if one sheet makes two leaves; also how wide the cloth binding must be, allowing one-half inch on each side for pasting, etc.

In sewing - seat-work - he makes his leaves and sews them together.

In nature study that day he perhaps adds to his vocabulary, five words, printed or written, which he will place in his dictionary for reference and use.

The drawing and painting demanded in this case would probably be only the drawing and painting of the stenciled word "Dictionary" for the front of the book.

Just as much of each activity is exercised as is necessary to make the object fulfill its purpose in the best way. If more space were taken, almost any central subject of study would illustrate this point better, for it would not only offer opportunities 
for closer correlation of work, but its proper study would illustrate the demand for reading and the various forms of expression.

By comparing this program with the outline of work for the First Grade, it will be noticed that nature study and geography deal with our winter conditions, our food, clothing, and physical environment. This is supplemented in history and geography by the study of the Eskimo, who has the same conditions intensified. In cooking, the fats and oils are studied because at this season they are prominent in the daily food of both peoples. The children have also the added interest of making and serving a good "fatty" food, i. e., butter at luncheon.

Number is demanded for clear picturing at every step. The teacher knows what the children already have as usable knowledge and ability in mathematics, and is aware what the new work may add to that store. This is also true in language and spelling, while the music, literature, and oral reading directly reinforce the other work.

In the library periods the children will be taken to the library, where Miss Warren prepares the books and pictures bearing upon the month's work. Here they will read silently, with the teacher's help.

In the next lesson in the subject thus studied each child will write what he has found out for the benefit of the entire class. This is always one of the most profitable periods of the week, and where the children have not access to a library the same general results can be obtained in the regular class-room from the use of selected supplementary readers and reading slips. The rhythm, ten-minute run, and the physical training provided for by the program mean rest and added power in every line of work-more strength, greater power of attention, and self-control.

In manual training this month the necessity for a towel-rack and dish-pan boards in the lunch-room is a more pressing need to the children every day when they wash their dishes than any demand for work in wood presented by the subjects studied. In doing this work in committees the children will not only apply their knowledge gained last month in the study of wood, and increase their power and skill in manual work, but they will also feel their usefulness to the community in a wholesome way and begin to appreciate and assume class responsibilities.

In summing up this work it is frankly admitted that it is most crude. This article is not written to defend it. The effort is to make the programs understood, and to show why reading, writing, and spelling are not given more definite places on these programs. They are considered as intrinsic parts of all the work, and they come in daily - yes, almost every hour in the day-but they come in to help in definite image-growth, and as the exact action of the child's mind cannot be foretold, so the form of exercise for each period is left to the teacher's discretion, with the understanding that she is held responsible for the thought, expression, and actions of the normal children under her care. If the thought work is really good, the form work cannot be very poor.

The question has been asked during the past month how the subjects of study are chosen and the course of study planned. Under the general ideal of the school each teacher's part is as follows:

A special plan for each month is worked out in detail by the grade teacher. It is based upon the general year's plan for each department in the school, and upon what the teacher knows of her particular children.

It seems fair to say that the subjects selected would stand the following tests:

Each subject must be: Something concerning which the children have an in- 
dividual as well as a racial experience; something that will arouse a child's selfactivity-i. e., which presents or demands vigorous mental or physical action - a demand which a normal child will appreciate and respond to; something which will exert an influence in harmony with the ideal of the school.

The children will read, write, spell, and cipher in every subject; but the vital questions are: Will the particular work chosen arouse interest and sustain it? Is it really worth while in forming the child's habits of life and character?

\section{Explanation of the Changes of Program in the Primary Grades}

A change will be observed in the grade outlines for this quarter, the plan for the First and Second Grades being written by Mrs. Atwood, and that of the Third and Fourth by Miss Van Hoesen. The arrangement of placing two grades in one room with an adjacent recitation room seemed best on account of small roomspace and the crowded condition of the school. The plan of work, however, has not essentially changed with the change of teachers.

It will be noticed that in many cases the higher grade children will study the subjects selected for the lower grade in the general plan for the year given in the catalogue of the Chicago Institute. That prospectus was not intended as a fixed guide, however, but was merely a hypothesis for work, founded upon previous experience with the interests and development of children of corresponding ages.

This year, as the work is new to all of the children, it seems perfectly feasible for both grades occupying one room to study the same subjects, providing that the work be well chosen and so adapted as to arouse the best effort and activity of each child. Mechanically, this plan is most economical in its demand for pictures, specimens, and reading materials in the class-room.

Better opportunities for correlation in music, literature, oral reading, and all general exercises are also provided when all the pupils of a room are studying the same things, in a general way, in history and science, than when each grade is demanding conditions and appliances for an entirely different line of work. Special provision is made for children who manifest special interest or desire for other forms of work. 